\title{
Nature and origin of germline mutations in human tandem repeated loci
}

\author{
S. A. Kravchenko, L. A. Livshits
}

The Institute of Molecular Biology and Genetics

150 Zabolotny Str., Kyiv 03143, Ukraine

livshits@imbg.org.ua

\begin{abstract}
The literature and own data on nature and origin of germline mutations in human hypervariable mini-and microsatellite loci have been analyzed. Possible molecular mechanisms involved in the mutation process in genomic loci with different nature are discussed.
\end{abstract}

Keywords: minisatellite and microsatellite loci, germline mutations, mutation rate

Mutational variability is considered to be the important source of diversity of inherited features and the mutation tempo is one of the most important characteristics of mutagenesis in general. The data on the level of mutations in different genome regions are very significant for both understanding of the mechanism of mutational process proper and for prognosis of genetic load based on the effect of mutations. The data on mutability of some genome regions are of special importance in the search for informative markers, suitable for various tasks and population investigations.

Previous research revealed the level of inherited mutations in humans to depend on the genome region and to vary widely from $10^{-9}$ for unique sequences up to $10^{-2}$ for microsatellite sequences, and even to $10^{-1}$ for some minisatellite sequences [1-3].

(c) S. A. KRAVCHENKO, L. A. LIVSHITS, 2007
There are several approaches to study the levels of inherited mutations:

- family approach - direct investigation of inheritance of alleles from parents to descendants [4-6];

- direct approach - investigation of mutations in germ cells directly, in spermatozoid in particular [7];

- phylogenetic approach - the comparison of phylogenetic tree of alleles of polymorphic loci of similar species (this approach allows evaluating historical accumulation of mutations; one of the variants of this approach is the study of unevenly bound loci, for instance, from genome of some sort of disease with the possibility of tracing the mutations in a significant number of generations) $[8,9]$;

- assessment of mutation rates in vitro in biological systems (may be applied for investigations of both spontaneous mutation rates and mutagenetic influence of different factors) [10]; 
- mathematic modelling approach for simulation of mutagenetic process on the basis of existent division of frequencies of polymorphic loci alleles [11].

The investigation of mutagenetic process in human genome was highly accelerated by the discovery of polymorphism of tandem repeated DNA sequences in human genome, which reflects the mutagenetic processes in these genomic loci.

Minisatellites or VNTR-loci - General characteristics of minisatellite loci. It was in the beginning of 1980's when several groups of scientists discovered and characterized specific hyper-variable regions in human genome. These regions were discovered in the close proximity to insulin and alpha-similar globin genes, apolipoprotein B gene, in the first intron of myoglobin gene, as well as in many other regions of human genome $[12,13]$. The common characteristic of the aforementioned hypervariable regions was the presence of sequences which included short (several dozens of nucleotides) tandem concentrated repeats. Later on this type of sequences was called minisatellites. Opposite to classical satellite DNA, minisatellites are not associated with centromeric heterochromatin and basically occur in telomeric and sub-telomeric regions of human genome [14].

The analysis of several diverse minisatellites revealed the common core region, 10-15 b.p. long, which is possible to function as a signal of recombination at the formation of polymorphic minisatellite regions [15]. The division of minisatellite loci on the chromosome confirmed this hypothesis as telomeric genome regions, where generally minisatellites appear, are specific for a rather high recombinant level [16]. The opposite telomeric regions of autosomes were determined to include approximately the same amount of minisatellite loci, yet minisatellites of $\mathrm{X}$-chromosome telomeric regions differed significantly [17]. There were only several minisatellite loci, which were identified on germ-specific part of X-chromosome, the region, where recombinant events do not take place during meiosis in male. And vice versa, pseudo-autosomic region was observed to reveal a high recombinant level, represented by a significant amount of minisatellites [18]. There was only one minisatellite locus (D17155S1) revealed in pseudo-autosomic region of this chromosome during Y-chromosome mapping [19].

Polymorphism of minisatellite loci. The Southern method of hybridisation was the basis for DNA-typing of

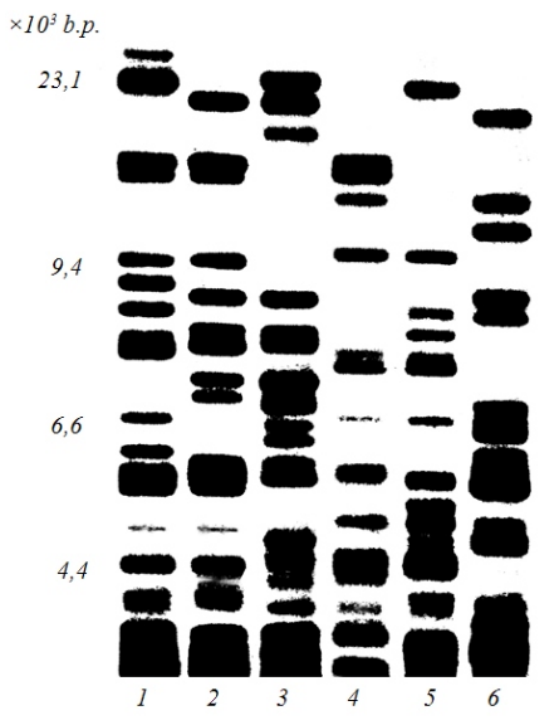

Fig.1 Analysis of DNA "finger-prints" of different individuals (according to A. Jeffreys et al. [21]): 1-6 individuals with sets of hybridisation bands of different width

hypervariable regions till 1990's. A. Jeffreys et al. were the first to construct 33.6 and 33.15 probes on the basis of minisatellite of myoglobulin intron sequence, which "recognised" different hyper-variable regions of DNA [20]. The pictures of hybridisation, obtained using this method, indeed demonstrate simultaneous detection of a great number of minisatellite regions in human genome, many of which are polymorphic, i.e. they contain different numbers of repeated elements in different individuals. Visibility-wise this multi-loci polymorphism was revealed on autoradiographic devices as the set of hybridisation lines of different length, which were also called DNA “finger-prints" (Fig.1).

The level of heterozygosity of these multi-loci DNA finger-prints in the investigated population was very high and reached almost $100 \%$. It is noteworthy that this high polymorphism level of minisatellite loci is considered to be one of the most important characteristics of hypervariable regions of human genome [21]. However, the application of Southern method hybridisation to analyse multi-loci polymorphism of minisatellite loci was specific for its, rather significant, specific disadvantages i.e. in the cases, when minisatellite loci were a part of relatively large DNA fragments, it was hard, if possible at all, to identify alleles, different from each other in several nucleotide pairs only. Besides, alleles of dif- 


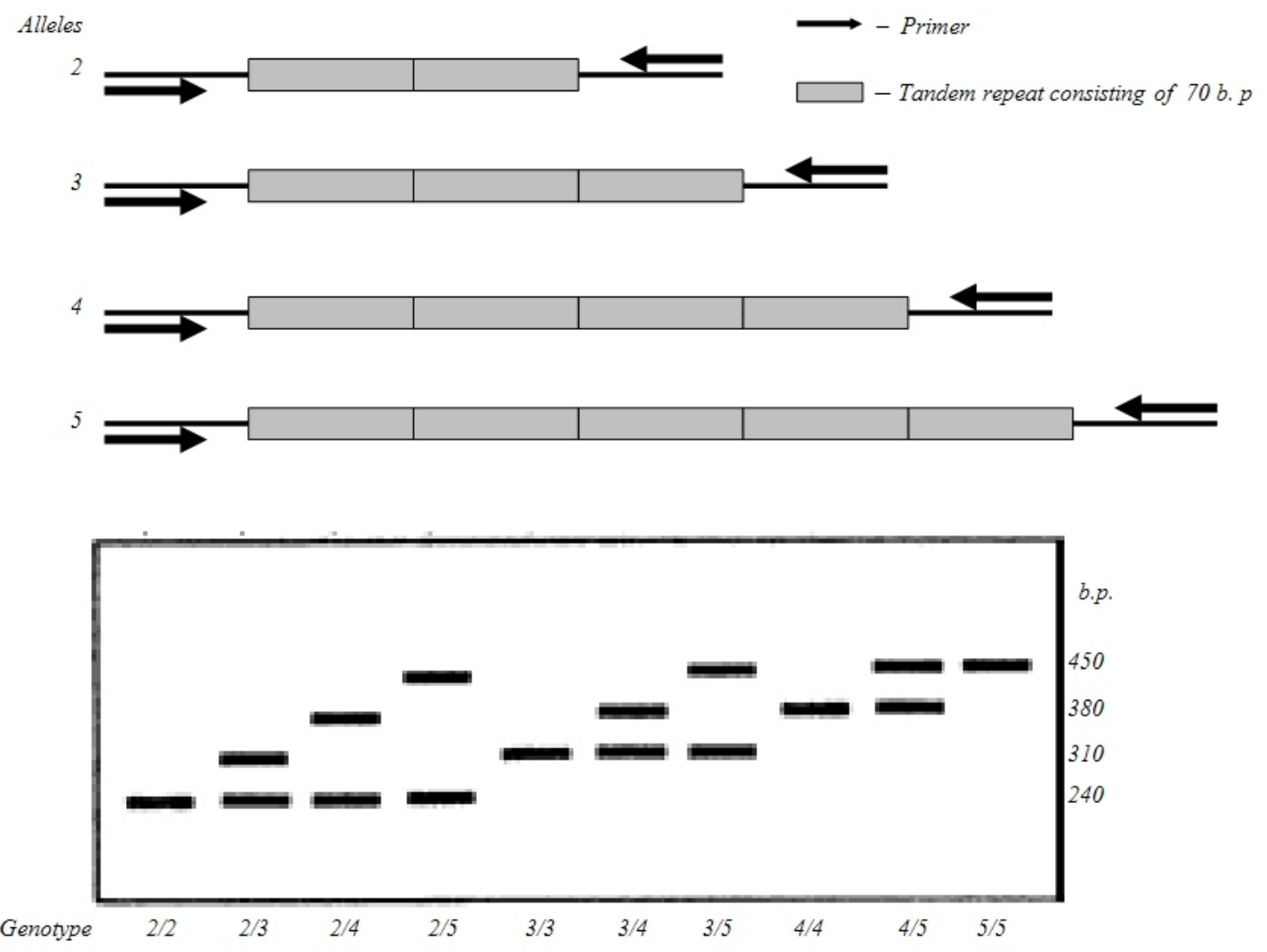

Fig.2 Schematic representation of different alleles of four-allele VNTR-locus and typing of different genotypes during electrophoretic separation of PCR products

ferent loci may be of the same size of hybridisation fragments, which results in impossibility to study one of the main characteristics of polymorphic locus, i.e. population frequency of certain alleles.

Rapid development of the method of in vitro DNA amplification [22], which is based on polymerase chain reaction (PCR), was the key factor in the change of situation with analysing hypervariable loci, as this method allowed removing the restrictions, limiting the effectiveness of their application as markers of different genome regions. Having applied certain oligonucleotide primers, compliment to the investigated region of chromosome, and thermostable DNA-polymerase, it is possible to amplify any specific fragment of genomic DNA with minisatellite loci included. Different alleles of minisatellite locus vary in the number of tandem repeats it consists of. Therefore, minisatellite loci obtained a new name on PCR discovery - VNTR-loci or loci with varied number of tandem repeats. Thus, different alleles of polymorphic locus may be of different length and, as a consequence, different migration mobility during electrophoretic separation of PCR products (Fig.2).

Several hundreds of single-locus VNTR-systems, the majority of which is highly-polymorphic (heterozygosity level exceeds $80 \%$ ) have been discovered nowadays, which enables their effective application as genetic markers in versatile fields of biology and medicine.

Microsatellites or STR-loci - General characteristics. The beginning of 90's of the previous century was rich for the works of different scientific groups, who characterised the new type of repeated sequences in human genome - microsatellite loci [23, 24]. Both minisatellites and microsatellites consist of tandem repeats, but the repeated motif varies from $2 \sim 6$ b.p. These loci were called short tandem repeats (STR-loci) [25]. In contrast to VNTR-loci, basically located in telomeric regions of chromosome, STR-loci are dispersed along human genome and occur every $6-1010^{3}$ b.p. Polymorphic microsatellite sequences were detected in both not encoding intergenic and encoding re- 
Table 1.

Diseases caused by the expansion of trinucleotide repeats

\begin{tabular}{|c|c|c|c|c|}
\hline \multirow{2}{*}{ Disease } & \multirow{2}{*}{$\begin{array}{l}\text { Localisat } \\
\text { ion }\end{array}$} & \multirow{2}{*}{ Repeat } & \multicolumn{2}{|c|}{$\begin{array}{c}\text { Number of gene } \\
\text { copies }\end{array}$} \\
\hline & & & Norm & Pathology \\
\hline $\begin{array}{l}\text { Fragile X Syndrome } \\
\text { (FRAXA) }\end{array}$ & $\mathrm{Xq} 27.3$ & CGG & $5-50$ & $>200$ \\
\hline $\begin{array}{l}\text { Fragile X Syndrome } \\
\text { (FRAXE) }\end{array}$ & $\mathrm{Xq} 27.3$ & GCC & $6-25$ & $>200$ \\
\hline $\begin{array}{l}\text { Fragile X Syndrome } \\
\text { (FRAXF) }\end{array}$ & $\mathrm{Xq} 28$ & GCC & $12-26$ & $>900$ \\
\hline $\begin{array}{l}\text { Spinal and Bulbar } \\
\text { Muscular Atrophy }\end{array}$ & Xq11-12 & CAG & $17-26$ & $40-52$ \\
\hline Myotonic dystrophy & $19 q 13.3$ & CTG & $5-27$ & $50-1600$ \\
\hline $\begin{array}{l}\text { Huntington's } \\
\text { hereditary chorea }\end{array}$ & $4 \mathrm{p} 16.3$ & CAG & $11-34$ & $>42$ \\
\hline $\begin{array}{c}\text { Spinocerebellar } \\
\text { ataxia }\end{array}$ & $6 \mathrm{p} 21.3$ & CAG & $25-36$ & $43-81$ \\
\hline $\begin{array}{c}\text { aultMachado-Joseph } \\
\text { disease }\end{array}$ & $14 \mathrm{q} 32.1$ & CAG & $13-36$ & $68-79$ \\
\hline Friedreich's ataxia & $9 \mathrm{p} 13$ & GAA & $7-22$ & $291-900$ \\
\hline
\end{tabular}

gions of human genome [26]. The most common microsatellites are dinucleotide repeats, which are the most common to include AC nucleotide pairs on one DNA chain and GT on the other one. Some other STR-loci, consisting of three-, tetra-, and pento-nucleotide repeated motives were also described. STR-loci differ not only in nucleotide content of tandem repeats, but also in the number of them: low variation loci consist of tandem repeats, the number of which does not exceed 15; medium variation loci may include up to 25 tandem repeats, and, finally, high variation loci may include more than 25 tandem repeats [27].

Regardless of the fact that STR-loci are included in both encoding and not encoding regions of human genome, the issue of their possible generally-biological role remains unsolved. The literature contains some hypotheses regarding the functions of some individual microsatellites. Thus, the proteins, capable of specific binding with some di- and trinucleotide repeats as a part of DNA [28], one of them, at least, may be involved in the process of accumulation nucleosomes in vitro [29], were identified. The evident role of trinucleotide repeats in cases of fragile X-chromosome, myotonic dystrophy,
Huntington's hereditary chorea, and some other neurodegenerative disease was determined (Table 1). This new class of hereditary diseases is distinguished on the basis of the main mechanism - dynamic mutation. Dynamic mutation is the increase (expansion) of the number of copies of trinucleotide repeats in the consecutive generations of a certain genus.

Expansion of the repeats is accompanied by the disease occurring at a higher threshold number of these repeats. Rapid increase in the number of repeats is determined to be the reason of complete termination of transcription corresponding or closely located genes, which results in the aforementioned diseases [30]. The reverse dependence of the number of trinucleotide repeats with transcriptional dependence of genes, which those genes include, was demonstrated [31].

Possible molecular mechanisms of minisatellite and microsatellite instability. The whole series of investigations revealed that minisatellite and microsatellite loci are specific for a high level of hereditary mutations $[3,5,32,33]$. The main types of mutations in these loci are deletions and insertions of tandem repeats, which are included into mini- and microsatellite loci. Microsatellite and minisatellite polymorphism is explained by means of variation in number of tandem repeated units. Exact mechanisms resulting in this instability remain unknown, yet the majority of the data, obtained either in human culture in vitro or in model Escherichia coli experiments, indicate that the main role in mutation process in minisatellite loci is performed by gene conversion [34]. Errors DNA replication replication slippage - is considered to be the source of mutation of microsatellite loci [30].

The increased mutation frequency of minisatellite loci was called minisatellite instability (MNI). The mutation rate of certain minisatellite loci may vary significantly, but for the majority of loci it amounts to $2 \cdot 10^{-4}$ [32]. The main mechanism of formation of the mentioned mutations is the process of genetic conversion during recombination [34].

Genetic conversion is the modification of one of two alleles by the other one. The final result of ge- 
netic conversion is similar to the result of double uneven crossing-over. The difference between these two processes lays in the fact that modification of one allele (target) after genetic conversion is non-reciprocal, as the other allele (source) remains unchanged. Practically it is impossible to differentiate between these two processes as it is impossible to analyse both products of recombination. Moreover, the changes in haplotypes both during genetic conversion and as a result of double uneven crossing-over are identical.

Concrete evidences for mechanism of formation of deletions (decrease in number of repeated sequences) and, especially, insertions (increase in number of repeated sequences) in male germ cells were obtained investigating the sequences with high mutation level in germ cells. Detailed analysis of nucleotide sequences of parent and mutant alleles of MS13 locus allowed A. Jeffreys et al. to prove that the majority of mutant variants (a part of deletions and all insertions) were formed as a result of the process of recombination [35]. At he same time the authors proved that insignificant part of mutations, deletions in particular, may be formed by means of loss of some part of the sequence. This process is most likely to take place as a result of double strand breaks (DSB), occurring in minisatellite loci and resulting in the formation of allele variants of different length after their repair [36]. Expected high level of mutations is conditioned by the fact that these mutations are the "hot spots" of recombination and double strand breaks.

High mutation frequency of microsatellite loci was called microsatellite instability (MCI). This notion was described in the beginning of 1990's. Non-specific for normal DNA, allele variants were observed in significant amounts (over 50\%) in DNA from patients' cancer cells of inherited non-polypous colorectal cancer [37]. The most of data indicate the main role in the mechanism of MCI is played by replication errors, namely, replication "slippages". At the same time DNA-polymerase is dissociated temporally in the replication fork accompanied by the formation of unpaired DNA regions. Later on repeated tandem unit is re-associated at a certain distance, but this time with no homologous repeat. The place of incorrect pairing is noted for the formation of a pin from the DNA fragment, while DNA-polymerase continues to complete DNA from the place of slippage. The formation of this kind of pins may take place in either one of newly synthesised chains and result in occurrence of deletions and insertions. This mechanism of replication slippage with subsequent formation of energy-stable structures of pin-types is evidently the reason of the increase in number of trinucleotide repeats in the cases of fragile X syndrome, myotonic dystrophy, Huntington's hereditary chorea, and of the whole series of other types of diseases of, so called, expansion of trinucleotide repeats kind [30]. Besides the formation of pins, other reasons of slippage of DNA-polymerase may be presented by other conformational changes in the DNA structure. Some literature data show that there can be formed special four-thread high-heat structures during local methylation of DNA in microsatellite loci, which results in violation of the replication process and leads to change in numbers of repeats [38].

The majority of data obtained nowadays show that it is the replication errors that take the main part in mutagenic process of microsatellite loci. The cell lines with violated repair system of nucleotide mismatch (mismatch-reparations) showed the rapid increase in the number of mutations, namely, MCI. On the other hand, DNA slippage is the inner-helix event, therefore, the mutation frequency should not depend on the chiasma frequencies. It was determined that mutations, eliminating recombination, influence the mutation rate neither in E. coli nor in Saccharomyces cerevisiae [40, 41]. There was established no link between the increased mutation frequencies in those genome microsatellite loci which are specific for high frequency of recombination and the same in human [4]. Finally, the main evidence of replicative nature of mutations is the fact that microsatellite loci, localised in non-recombinant region of human $\mathrm{Y}$-chromosome, show the mutation rate similar to autosomic loci, which is impossible for replication-related process $[5,33,42]$.

Preliminary research indicated different mutation rates for some microsatellite loci. For the majority of loci analysed hereto the average mutation rate is $2 \cdot 10^{-3}$ [5]. What factors influence mutability of microsatellite loci? The answers for the question of different mutation rates are most likely to be found in the localisation of a given locus on the chromosome, its structure, and contents. Thus, poly(GT)-tract of two yeast strains of 
S. cerevisiae (wild type and with deficient mismatch-repair system) revealed non-linear increase in instability with increase in allele length during investigation of mutation rates of alleles of 15, 33, 51, 99, and 105 b.p. Regardless of the fact that allele of 105 b.p. is only 7 times longer than allele of 15 b.p., the mutation rate for the former was shown to be 500 times higher. As this correlation was observed in both strains, it was possible to cross out the lower effectiveness of DNA repair system of one of the strains from the list of possible reasons [41]. Similar regularities were observed during investigations of human microsatellite [4, 42]. B. Brinkmann et al. [5] showed the mutation frequency in locus to be predominantly dependent on its contents, i.e. instability increased exponentially with the increase in the length of monotonously repeated tract. The insertions of the other nucleotide contents had a stabilising effect on DNA. Similar phenomenon was observed in the studies on diseases with the expansion of numbers of trinucleotide repeats, as well as on dinucleotide STR [40]. Therefore, different mutation capacities of loci and even different alleles as a part of one locus are, to a great extent, explained by the variations in their length and nucleotide contents.

Analysis of mutations of father's origin in minisatellite and microsatellite loci, performed in a whole series of investigations, showed that mutations occurred mainly in the course of gametogenesis in males. Evidently, the prevalence of father's mutations is a general tendency, specific for both minisatellite and microsatellite DNA sequences. According to B. Brinkmann et al. [5], the ratio of father's and mother's mutations in microsatellite loci was 17:3, while according to A. Sajantila et al. [6], 10 of 11 mutations occurred in father's gametogenesis. Alike tendency was demonstrated for minisatellite loci as well - our investigation [43] and Dubrova et al. showed that the reason of prevalence of father's mutation was most likely to be dependent on the fact that during maturation process, spermatozoids experience 10 times more cycles of replication than oocytes. 22 mitotic divisions take place in oogonia prior to meiosis in women regardless of age, whereas, the number of divisions which spermatozoids went through is dependent significantly on the age in men. For example, in 28-year-old men, spermia go through app. 380 mitoses, at $35-540$ mitoses (i.e. 16 and 25 times more that oocytes, respectively) [45]. If the difference in number of mutations in gametogenesis is indeed the consequence of dif- ferent numbers of cycles of DNA replication, then the dependence of frequency of father's mutations on the father's age has to be observed. This regularity was actually defined - average age of fathers with mutations in microsatellite loci was significantly higher than the average age of fathers with no mutations $[33,46]$. However, the absence of direct dependence between the ratio of number of mitoses in gametogenesis of different genders and the level of mutations may point at the existence of the influence by other factors. Male germ cell line DNA may differ from the female one in status of methylation, temperature modes, sensitivity to the effect of free oxygen radicals and some other potentially mutagenic compounds, produced by testicles [47].

More than $90 \%$ of mutations in minisatellite and microsatellite loci are expected to be of, so called, single step character and new alleles of polymorphic locus are formed in accordance to this model (SSM, single-step mutation) [48]. The essence of the model is explained as follows: whenever the state of allele is changed due to some sort of mutation (deletion or insertion), it will be substituted by one step towards positive or negative direction in allele space. Two-step mutations or multi-step mutations are rare to occur [5].

Therefore, opposite to unique genomic sequences with very low mutation frequency, the repeated sequences experience constant changes. The study on the regularities of mutations induced in mini- and microsatellite loci showed a series of important aspects in regards to application of these systems for genetic monitoring [49]. At the same time, the development of PCR method allowed clear and simple determining of allele variants of polymorphic minisatellite and microsatellite loci. Thus, special convenience in determining allele variants and high degree of polymorphism in mini- and microsatellite loci made them handy for application in different investigation tasks.

\section{Application of minisatellite and microsatellite loci as model systems for assessment of mutagenic and endogenic factors of genome instability. Re- cently, a large number of works suggesting the ap- plication of mini- and microsatellites as model sys- tems for assessment of mutagenic effect of factors of}


different origin have been published. Stating on rather a high level of spontaneous mutations of CEB minisatellites (up to 15\%) [3], it is expectable that these hypervariable loci would be of special interest not only as the objects of the research in terms of molecular and genetic mechanisms of spontaneous mutagenesis but also for clarifying the regularities of induced mutagenesis. Besides, it is quite possible to foresee their application as potential markers of mutagenic effect of ionising irradiation on the level of DNA. The data obtained by the authors from Japan, UK, and Ukraine, who studied the mutagenetic activity of ionising irradiation on hypervariable CEB minisatellites, were very interesting and contradicting at the same time.

Thus, Japanese authors showed the level of inherited mutations in minisatellite loci of descendants, born several years after their parents' surviving nuclear bombing in Hiroshima and Nagasaki in 1945, not to differ from the one of the control group. Hence, the conclusion on the absence of mutagenic effect of ionising irradiation on minisatellites of germ cells has been made [50].

Quite the opposite data were presented by British investigators. Dubrova et al. revealed almost 2-time increase in mutation frequency in minisatellite loci, comparing to the control group, performing the monitoring of radiationally induced mutations in the population of Mogilev oblast, Belarus, who resided on the territory, polluted by radionuclides as a result of Chernobyl disaster $[44,51]$. The same group of investigators showed that as a result of radioactive pollution during testing of nuclear weapons in Semipalatinsk Test Site, former Soviet Union, the frequency of induced mutations in minisatellite loci in the population, who had been living on this territory for many years, was two times higher in comparison to the control group [52].

Possible reasons for differences in the results presented may be connected with the following factors: first of all, nuclear bomb explosions in Hiroshima and Nagasaki brought up single-stage irradiation of inhabitants, whereas in the cases of Chernobyl disaster and nuclear testing in Semipalatinsk, the inhabitants were subdued to chronic irradiation for many years; second of all, the majority of Japanese children were born in 10+ years after explosions and in the course of this time the induced changes in the DNA structure could have been repaired by the repair systems.

We have carried out the investigation of induced mutations in minisatellite loci of children, whose parents were Chernobyl disaster fighters, together with French scientists. The analysis of mutation frequencies in children, conceived after fertilization of oocytes by spermia, which were under the influence of ionising irradiation (during the time of parents' being at Chernobyl Nuclear Power Plant) and children, conceived in four plus months on completion of their work at Chernobyl Nuclear Power Plant, showed that the level of inherited mutations in the first group was one and a half times higher than that of the second one. However, the difference discovered was shown to be statistically untrustworthy [43].

Along with minisatellite loci results, there were data obtained on the whole series of microsatellites, which indicate the propriety of their application as an instrument of genetic monitoring of mutagenic and endogenic factors of genome instability. It was determined that microsatellite instability of high frequency (up to $50 \%$ ) was observed in tumours of patients with small cell lung carcinomas, brain and neck tumours $(29 \%)$, and breast cancers (28\%). All these facts testify in favour of a significant role of genome instability of somatic cells in pathogenesis of malignant neoplasms $[53,54]$. A group of scientists from Greece defined the increased mutation frequency of microsatellites, not related to proto-oncogenes, in the cells of spontaneously aborted embryos [55]. The analysis of inherited tandem repeats in 21 different STR-loci of the families with spontaneous aborts performed by Russian investigators showed that the death of a significant number of human embryos with normal karyotype is associated with the increased level of mutations of microsatellites of gametic and somatic origin, which almost 5 times exceeds the level of spontaneous mutations of microsatellites [49]. Later on the same group of scientists from Russia carried out the investigation on gametic de novo mutations in the families with healthy children and in the families with spontaneous abortions with normal karyotype in order to analyse the mutational variability of microsatellites in meiosis and its possible connection with disorders in development of embryos. The miscarriage families showed the frequency of gametic muta- 
tions to be almost twice higher than that of families with normal reproductive function, i.e. $4.4 \cdot 10^{-3}$ and $2.3 \cdot 10^{-3}$, respectively, however, this difference was shown to be untrustworthy statistically $(\mathrm{P}=0.25)$ [56]. It has to be mentioned also minimal sampling amount is sometimes considered to be the main criterion in the studies of rare phenomena in comparative samples with the purpose of obtaining statistically trustworthy difference between them. Thus, the previous experience shows that only a few dozens or sometimes thousands of analysed alleles may provide more or less trustworthy information regarding new alleles and mutagenesis, which conditions their occurrence [57]. Of course it is a complicated and labour-consuming task, the solution of which may be achieved by joint efforts of many laboratories. The data presented may point at the fact that the increased mutation frequency in microsatellite loci is a good indicator of significant functional changes in the operation of cell genetic apparatus. There is a fact that testifies in favour of the latter statement, the cell lines, revealing microsatellite instability, also demonstrate the increase in mutation frequency of expressed genes [58].

Analysis of inherited mutations, occurring in some mini- and microsatellite loci of human germ cells. The analysis of spontaneous mutations of deletion-insertion type, occurring in minisatellite loci of germ cells and detected as the losses of a part of the sequence of minisatellite locus (deletion) or increase in the number of copies of tandem repeated units (insertion) has been performed by our group among the members of 163 families (mother, father, children) in the following seven hypervariable minisatellite loci: CEB1 (D2S90), CEB15 (D1S172), CEB72 (D17S888), CEB42 (D8S358), CEB36 (D10S473), CEB25 (D10S180) [59] and B6.7 (localised on chromosome 20 I q13 region) [60].

To evaluate the variability of alleles in the investigated populations we have performed the analysis of length spectra of fragments of hybridisation, obtained in the course of analysis of sequences in all seven minisatellite loci of fathers and mothers (unrelated individuals). A great number of allele variants revealed during the analysis testify in favour of a high level of mutations of the investigated minisatellite loci. Interestingly, five out of seven analysed loci were shown to have almost identical number of alleles (87-90). CEB42 allele spectrum was not so rich - only 77 variants were detected. Analysis of
CEB72 revealed the lowest number of different alleles -35 . The results of analysis of mutations of seven minisatellite loci of children revealed $64 \mathrm{mu}-$ tant allele variants, different from both fathers' and mothers'. The example of the analysis performed for CEB1 locus is presented in Fig.3. All children with the mutations revealed were confirmed in the biological paternity $(\mathrm{P}>99.99 \%)$ by the genotyping method of family members.

Table 2 presents the results of analysis of the numbers of mutations of mother's and father's origin, detected in children. The data obtained testify that the inherited mutations were registered for all seven types of analysed loci. CEB1 locus was shown to be the most mutable one. The interesting data were obtained for the spectrum of mutations, deletions and insertions in particular. Total percentage of deletions of father's origin calculated for all analysed loci was $39.61 \%$ and was statistically trustworthy lower than the percentage of insertions, revealed in $60.4 \%$ of cases. Analysis of mutation spectrum of mother's origin showed that the level of deletions was approximately the same and amounted to 54 and $46 \%$ respectively (differences untrustworthy statistically).

We have studied the division of allele variants of minisatellites, which mutated in germ cells of parents (fathers and mothers), as well as inherited mutant alleles of their children. The data obtained revealed that the most instable allele variants were those containing sequences of 2 to $5 \cdot 10^{3}$ b.p., which were the material for more than $70 \%$ of all children inherited mutations. In the case of this transformation newly-formed mutant alleles were of 2 to $3 \cdot 10^{3}$ b.p.

The analysis of sizes of insertions and deletions shows that the length of the lost (deletion) or acquired (insertion) sequence is average of 300 b.p. long.

Therefore, it is possible to bring up the supposition that mutagenesis and inheritance take place as a dynamic stabilising process, which supports the division of allele variants in population. Although, it has to be mentioned that the insertions dominated $(78.2 \%)$ in the total number of mutations in CEB1 locus, which was specific (according to the result of our investigation as well as the data from other au- 
Table 2.

Level of inherited mutations of mother and father origin in minisatellite loci of children

\begin{tabular}{|c|c|c|c|c|c|c|c|c|c|}
\hline \multirow{2}{*}{ Probe } & \multicolumn{3}{|c|}{ Father } & \multicolumn{3}{|c|}{ Mother } & \multicolumn{3}{|c|}{ Total } \\
\hline & $\begin{array}{l}\text { Number } \\
\text { of alleles }\end{array}$ & $\begin{array}{c}\text { Number of } \\
\text { mutations }\end{array}$ & $\begin{array}{l}\text { Level of } \\
\text { mutation }\end{array}$ & $\begin{array}{l}\text { Number } \\
\text { of alleles }\end{array}$ & $\begin{array}{c}\text { Number of } \\
\text { mutations }\end{array}$ & $\begin{array}{l}\text { Level of } \\
\text { mutation }\end{array}$ & $\begin{array}{c}\text { Number of } \\
\text { alleles }\end{array}$ & $\begin{array}{c}\text { Number of } \\
\text { mutations }\end{array}$ & $\begin{array}{l}\text { Level of } \\
\text { mutation }\end{array}$ \\
\hline CEB 1 & 163 & 23 & 0.1411 & 163 & 0 & - & 326 & 23 & 0.071 \\
\hline CEB 15 & 153 & 5 & 0.0327 & 153 & 0 & - & 306 & 5 & 0.016 \\
\hline CEB 36 & 160 & 0 & - & 160 & 4 & 0.0250 & 320 & 4 & 0.013 \\
\hline CEB 42 & 150 & 1 & 0.0067 & 150 & 1 & 0.0067 & 300 & 2 & 0.007 \\
\hline CEB 72 & 161 & 4 & 0.0248 & 161 & 4 & 0.0248 & 322 & 8 & 0.025 \\
\hline
\end{tabular}

thors) for extremely high mutability level (14.11\%), notably in male germ cells only [3,51]. Thus, based on the data of investigations carried out, the supposition can be made that predominant majority of inherited mutations was formed in male germ cells. The fact that CEB1 locus experienced the surplus of insertions, i.e. mutations, resulting in increase in the number of tandem repeated sequences may testify in favour of the fact that the main mechanism of mutagenesis in these minisatellite sequences is, most likely, the genetic conversion, which takes place during meiotic recombinant events in the course of gametogenesis.

The investigation of the level of gametic mutations (deletions/insertions) was performed by our group using our minisatellite loci as well - APOB (2p23-p24.2q), PYNZ22 (17p13), IGHJ (14q32.33), PMCT118 (chromosome 1). These minisatellite loci were used to analyse 1106 meioses -553 of fathers and 553 of mothers. The analysis of allele variants from fathers to children revealed any inherited mutations in neither one of these four minisatellite loci. Therefore, different minisatellite loci were determined to have unequal levels of mutation, as in minisatellite loci of CEB group, located in sub-telomeric regions of genome, the mutation level was shown to be much higher, compared to minisatellite loci APOB, PYNZ22, IGHJ, and PMCT118.

To determine the level of gametic mutations (deletions/insertions) in nine autosomic microsatellite loci (2AE9.1, Rep4-cf, VWF-8, VWA, FGA, TH01, D21S11, D7S820, D8S1179) we have analysed the in- heriting of allele variants from parents to children. All microsatellite loci were used to study 6400 meioses 3200 of fathers and 3200 of mothers. The study revealed six inherited mutations. Thus, D21S11 had one mutation of mother's origin. This mutation was presented by dinucleotide deletion of allele 10 in 9, i.e. in the course of meiosis in mother's organism the mutation of allele of 231 b.p. long brought up the formation of a new allele of 229 b.p. long, inherited by the child. We defined two mutations of father's origin in WVA locus - tetranucleotide insertions of alleles 19 into 20 (Fig.4) and 18 into 19, i.e. the spermatogenesis was specific for the mutations of alleles of 158 b.p. long and the formation of 163 b.p. long allele in the first case and the allele of 154 b.p. long in the second case of 158 b.p. long allele. 2AE.9 and D8S1179 loci were shown to include deletions of father's origin and locus D7S820 insertion of father's origin. Therefore, the results of our investigations show that the level of mutations of mother's origin in D21S11 locus is $1.7 \cdot 10^{-3}(1 / 580)$. The levels of mutations of father's origin in the microsatellite loci were detected to be as follows: WVA $-3.4 \cdot 10^{-3}(2 / 588) ; 2$ AE. $9-8.8 \cdot 10^{-3}(1 / 114)$; D7S 820 $2.6 \cdot 10^{-3}(1 / 390)$; D8S1179 - 2.6 $10^{-3}(1 / 380)$.

Noteworthy is the fact that in all cases the biological paternity was confirmed by $99.99 \%$ probability. It has to be mentioned as well that the absolute indices of the mutation level, defined by us, were of relative nature as the analysed number of meioses may be considered as only representative in the assessment of rather rare cases of mutations. Cumulative indices of levels of 


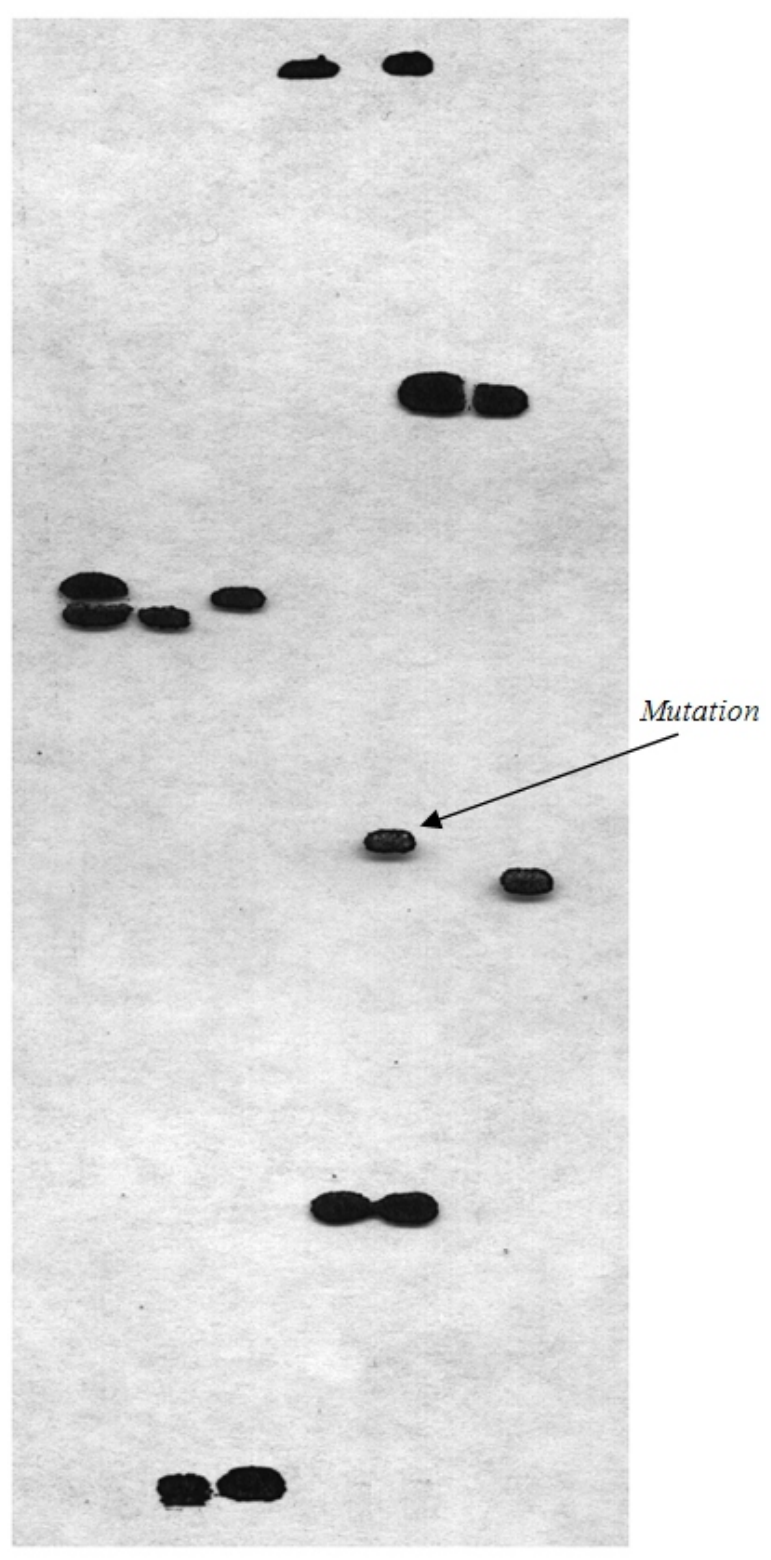

Fig. 3 Analysis of inherited mutations in CEB1 human locus by blot-hybridisation: 1, 3, 4, 7 - parents; 2, 6 - children without mutations; 5 child with mutant allele of locus CEB1

mutations, calculated by us for all the autosomic microsatellite loci were as follows: $3.1 \cdot 10^{-4}(1 / 3200)$ and $3.6 \cdot 10^{-3}(5 / 3200)$ for mutations of father's and mother's origin respectively.

To determine the level of gametic mutations in nine STR-loci of Y-chromosome (DYS19, DYS390, DYS391, DYS392, DYS393, DYS389I, DYS389II, DYS385a/b) we performed the analysis of the index of inheritance of allele variants. We analysed 1953 meioses in regards to all microsatellite loci of Y-chromosome. The deletion in
DYS19 and insertions in DYS390 and DYS389I were determined. Therefore, the cumulative index of the level of mutations for microsatellite loci of Y-chromosome was determined to be $1.5 \cdot 10^{-3}$ (3/1953) (www.yhrd.org/index.html).

It is noteworthy also that all mutations discovered by us were of single-step nature. These data correlate well with the proposed SSM-model, which explains the formation of new alleles and, consequently, polymorphism of microsatellite loci [48].

Stating on the indicated level of spontaneous mutations, specific for CEB minisatellites, it is possible to expect that these hypervariable loci present a significant interest not only as the object of the research of molecular and genetic mechanisms of spontaneous mutagenesis but for clarifying the regularities of induced mutagenesis. Besides, it is possible to foresee their application as potential markers for the investigation of mutagenic effect of ionising irradiation at the level of DNA.

In regards to the stated-above we have investigated seven hyper-mutable minisatellite loci of CEB group on the children, whose parents were Chernobyl disaster fighters (1986-1987). The highest mutability level was observed in CEB1 locus. As it has been noticed above, the level of mutation for this locus in the control group was $14 \%$. In the cases of children, whose parents were Chernobyl disaster fighters, the mutations in this locus were more common - more that $15 \%$ of cases. The same tendency was observed in the cases of mutations in B6.7 and CEB36 loci. Yet the increase in the level of mutations in this type of children, comparing to the one of children of the control group were not trustworthy statistically. The dependence of the age of parents and the occurrence of mutations of father's origin in both groups was not studied.

To evaluate possible differential sensitivity of some stages of development of male germ cells prior to mutagenic influence of ionising irradiation, the group of children, whose parents were Chernobyl disaster fighters, was divided into two subgroups. The first subgroup included children, conceived in the period of or not later than in two-month term after completion of their parents' work at Chernobyl Nuclear Power Plant. The children, conceived in the 


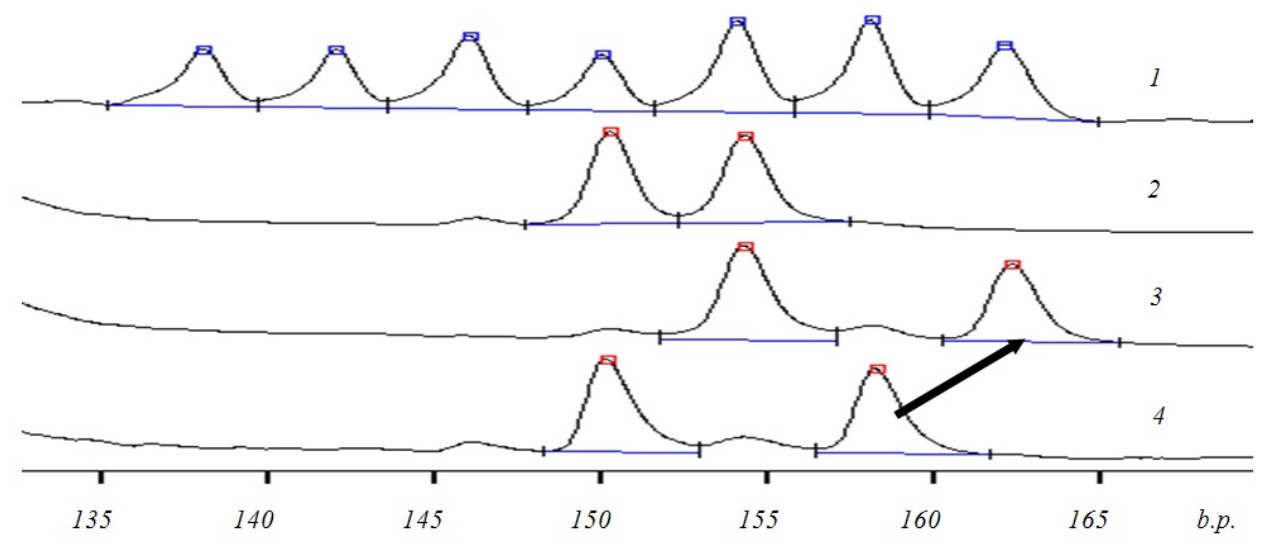

Fig.4 Mutation in WVA locus: 1 - marker "allele ladder"; 2 mother (genotype 17/18); 3 child (genotype 18/20); 4 - father (genotype 17/19) period of four plus months after their parent finished forking at Chernobyl Nuclear Power Plant, belonged to the second subgroup. This division was based on the fact that the period of spermatogenesis lasts 64-73 days. The dates of birth of children were indicated in parents' applications. The result obtained revealed the total level of mutations of father's origin of children of the first subgroup to be one and a half times higher, than the same index of the second subgroup.

The results obtained do not provide any single answer to the question whether the ionising irradiation influences the level of inherited mutations in minisatellite loci of children, whose parents were Chernobyl disaster fighters, born after 1986. However, if the tendency in the increase in the levels of mutations in the group of children, conceived after fertilisation of mother's oocytes with spermia, under the influence of ionising irradiation (in the time of parents' working at Chernobyl Nuclear Power Plant) is not accidental, then the obtained data in two subgroups of children from the families of Chernobyl disaster fighters allow concluding that possible mutagenic effect was to take place in the course of spermatogenesis only, i.e. it does not involve stem germ cells, as it has been reported by Dubrova et al [44, 51].

Regarding to the aforementioned, it is possible to suppose that if there is any genetic effect of mutagenic influence of ionising irradiation on minisatellite loci of genome of germ cells, then its effect is limited to short period of spermatogenesis and its influence is not essential for germ cells, which enter the stage of meiosis after the effect of ionising irradiation. The data obtained by Japanese scientists show the same results - no apparent increase in the levels of inherited mutations in minisatellite loci of descendants, born several years after their parents surviving nuclear bombings of Hiroshima and Nagasaki [50].

Summarising on the facts mentioned above, it is worthy to note that genome stability may be revealed using the analysis of repeated DNA sequences. Inner-genetic location of a number of repeated sequences, their variabilities, clearly visible Mendelian type of inheritance make them very perspective for genetic monitoring of mutagenic environmental factors, as well as inherited tendency to disorders in embryogenesis and carcinogenesis. The bulk of investigation, aimed at the assessment of mutability of various regions of human genome, demonstrate that the interest in this problem is far from being vanished, but gains new rapid development, provided by the novel methods in the investigation of mutations. The accumulation of the experimental data on the family analysis, the application of modern methods for detection of deletions/duplications using real-time PCR, the development of novel methods of mathematic modelling of the mutagenesis with the separation of frequencies of polymorphic alleles in different populations will result in obtaining new data on the nature and the level of mutations of different regions of human genome.

\section{С. А. Кравченко, Л. А. Лівшиць}

Природа та походження успадкованих мутацій у тандемно повторюваних ділянках геному людини

Резюме

Проаналізовано літературні та власні дані дослідження природи та походження успадкованих мутацій $y$ гіперваріабельних мінісателітних та мікросателітних 
локусах геному людини. Розглянуто можливі механізми, залучені до мутаційного процесу в локусах різної природи.

Ключові слова: мінісателітні та мікросателітні локуси, успадковані мутації, мутаційний рівень.

\section{REFERENCES}

1. Nei M. Molecular evolutionary genetics.-New York: Columbia Univ. press, 1987.-512 p.

2. Weber J. L., Wong C. Mutation of human short tandem repeats // Hum. Mol. Genet.-1993.-2.-P. 1123-1128.

3. Vergnaud G., Mariat D., Apiou F., Aurias A., Lathrop M., Lauthier $V$. The use of synthetic tandem repeats to isolate new VNTR loci: cloning of a human hypermutable sequence // Genomics.-1991.-11.-P. 135-144.

4. Huang Q.-Y., Xu F.-H., Shen H. Mutation pattern at dinucleotide microsatellite loci in humans // Hum. Ge- net.-2002.-70.-P. 625-634.

5. Brinkmann B., Klintschar M., Neuhuber F. Mutation rate in human microsatellites: influence of the structure and length of the tandem repeat // Am. J. Hum. Genet.-1998.62.-P . 1408-1514.

6. Sajantila A., Lukka M., Syvanen A. C. Experimentally observed germline mutation at human micro- and minisatellite loci // Eur. J. Hum Genet.-1999.-7.- P. 263-266.

7. Holtkemper U., Rolf B., Honoff C. Mutation rates at two human Y-cromosomal microsatellite loci using small pool PCR techniques // Hun. Mol. Genet.-2001.-10.-P. 629-633.

8. Bowcock A. M., Ruiz-Linares A., Tomfohrde J., Minch E., Kidd J. R., Cavalli-Sforza L. L. High resolution of human evolutionary trees with polymorphic microsatellites // Nature.- 1994.-368.-P. 455-457.

9. Santibanez-Koref M. F., Gangeswaran R., Hancock J. M. Relationship between length of microsatellites and nearby substitution rates in mammalian genomes // Mol. Biol. Evol.-2001.-18.-P. 2119-2123.

10. Lee J. S., Hanford M. G., Genova J. L., Farber R. A. Relative stabilities of dinucleotide and tetranucleotide repeats in cultered mammalian cells // Hum. Mol. Genet.-1999.-8.-P. 2567-2572.

11. Chakraborty R., Kimel M., Stivesr D. M. Relative mutation rates at di-, tri-, and tetranucleotide microsatellite loci // Proc. Nat. Acad. Sci. USA.-1997.-94.-P. 1041-1046.

12. Bell G. J., Selby M. J., Rutter W.J. The highly polymorphic region near the human insulin gene is composed of simple tandemly repeating sequences // Nature.-1982.-295.-P. 31-35.

13. Jarman A. P., Higgs D. R. A new hypervariable marker for the human alpha-globin gene-cluster // Am. J. Hum. Genet.-1988.-43.-P. 249-256.

14. Nakamura $Y$. A primary map of ten DNA markers and two serological marcers for human chromosome 19 // Genomics.-1988.-3.-P. 67-71.

15. Weber J. L. Human DNA polymorphisms and methods of analysis // Curr. Opin. Biotechnol.-1990.-1.-P. 166-177.

16. Jarman A. P., Wells R. A. Hypervariable minisatellites: recombinators innocet bystanders? // Trends Genet.-1989.-5.P. 367-371.

17. Freije D., Helms S., Watson M. S., Donis-Keller H. Identification of a second pseudoautosomal region near the $\mathrm{Xq}$ and Yq telomers // Science.-1992.-N 5089.- P. 1784-1787.

18. Cooke H. J., Broun W. R., Rappold G. A. Hypervariable telomeric sequences from the human sex chromosomes are pseudoautosomal // Nature.-1985.-317.-P. 687-692.

19. Joblin M., Tyler-Smith C. Fathers and sons: the Y chromosome and human evolution // Trends. Ge- net.-1995.-11.-P. 449-456.
20. Jeffreys A., Wilson $V$. , Thein $S$. Hypervariable «minisatellite» regions in human DNA // Nature.-1985.-314.-P. 67-73.

21. Jeffreys $A$., Wilson $V$., Thein $S$. Individual-specific «fingerprints» of human DNA // Nature.-1985.-316.P. 76-79.

22. Saiki R. K., Gelfand D. H., Stoffel S. Primer directed enzymatic amplification of DNA with a thermostable DNA polymerase // Science.-1988.-239.-P. 487-491.

23. Weber J. L., May P. E. Abundant class of human DNA polymorphisms wich can be typed using the polymerase chain reaction // Am. J. Hum. Genet.-1989.-44.-P. 388-396.

24. Koschinsky M. L., Beisiegel U., Eaton D. L. Apolipoprotein (a) sixe heterogeneity is related to variable number of repeat sequences in its mRNA // Biochemistry.-1990.-29.- P. 640-644.

25. Litt M., LutyJ. A hypervariable microsatellite revealed by in vitro amplification of a dinucleotide repeat witkin the cardiac muscle actin gene // Am. J. Hum. Genet.-1989.-44.- P. 397-401.

26. Edwards A. I., Civitello A., Hammond H. A., Caskey C. T. DNA typing and genetic mapping with trimeric and tetrameric tandem repeats // Am. J. Hum. Genet.-1991.-49.-P. 746-756.

27. Brinkman B., Junge A., Meyer E. Population genetic diversity in relation to microsatellite heterogeneity // Hum. Mutat.-1998.-11.-P. 135-144.

28. Сломинский П. А., Шадрина М. И., Лимборская С. А. Выявление белка, специфически связывающегося с триплетным повтором типа (CTG) $n$ // Молекуляр. биология.-1997.-31, № 1.-C. 45-48.

29. Wang Y. H., Gellibolian R., Shimizu M. Long CCG triplet blocs exclude nucleosomes: a possible mechanism for the nature of fragile sites in chromosomes // J. Mol. Biol.-1996.-263.-P. 511-518.

30. Гайихоки В. С., Паткин Е. Л. Сателлитные ДНК и болезни - возможные механизмы. Тринуклеотидные повторы // Генетика.-2000.-36, № 7.-C. 869-886.

31. Giovannucci E., Stampfer M. J., Krithivas K. The CAG repeat within the androgen receptor gene and its relationship to prostate cancer // Proc. Nat. Acad. Sci. USA.-1997.-94.- P. 3320-3323.

32. Jeffreys $A$. J. Spontaneous mutation rates to new length alleles at tandem-repetitive hypervariable loci in human DNA: Complex gene conversion events in germline mutation at human minisatellites // Nature.-1988.-332.-P. 278-281.

33. Kayser M., Roewer L., Hedman M. Characteristic and frequency of germline mutations at microsatellite loci from the human $\mathrm{Y}$ chromosome, as revealed by direct observation in father/son pairs // Am. J. Hum. Genet.-2000.-66.- P. 1580-1588

34. Jeffreys A., Tamaki K., Mac Leod A., Monckton D., Neil D., Armor J. Complex gene conversion events in germline mutation at human minisatellites // Nat. Genet.-1994.-6.P. 136-145.

35. Jeffreys A., Neil D. L., Neumann R. Repeat instability at human minisatellites arising from meiotic recombination // EMBO J.-1998.-17.-P. 4147-4157.

36. Debrauwere H., Buard J., Tessier J., Aubert D., Vergnaud G., Nicolas A. Meiotic instability of human minisatellite CEB1 in yeast requires DNA double-strand breaks [In Process Citation] // Nat. Genet.-1999.-23.-P. 367-371.

37. Thibodeau S. N., Bren G., Schaid D. Microsatellite instability in cancer of the proximal colon // Lancet.-1993.-260.- P. 816-819. 
38. Jones P. A., Gonzalgo M. L. Altered DNA methylation and genome instability: A new pathway to cancer? // Proc. Nat. Acad. Sci. USA.-1997.-94.-P. 2103-2105.

39. Bapat B. V., Madlensky L., Temple L. K. Family history characteristics, tumor microsatellite instability and germline MSH2 and MLH1 mutations in hereditary colorectal cancer // Hum. Genet.-1999.-104.-P. 167-176.

40. Heale S. M., Retes T. D. The stabilization of repetitive tracts of DNA by variant repeats requires a functional DNA mismatch repair system // Cell.-1995.-83.-P. 539-545.

41.Wierdl M., Dominska M., Petes T. D. Microsatellite instability in yeast: dependence on the length of the microsatellite // Genetics.-1997.-146.-P. 769-779.

42. Xu X., Peng M., Fang Z., Xu X. The direction of microsatellite mutations is dependent upon allele length // Nat. Genet.-2000.-24.-P. 396-399.

43. Livshits L. A., Malyarchuk S. G., Lukyanova E. M., Antipkin Y. G., Arabskaya L. P., Kravchenko S. A., Matsuka G. H., Petit E., Giraudeau F., Gourmelon P., Vergnaud G., Le Guen $B$. Children of chernobyl cleanup workers do not show elevated rates of mutations in minisatellite alleles // Radiat. Res.-2001.-155.-P. 74-80.

44. Dubrova Y., Nesterov V., Krouchinsky N., Ostapenko V., Neumann R., Neil D. L., Jeffreys A. J. Human minisatellite mutation rate after the Chernobyl accident // Nature.-1996.360.-P. 683-686.

45.Фогель Ф., Мотульски А. Генетика человека (в 3 т.).-М.: Мир, 1990.

46. Rolf B., Brinkmann B. Reply to Henke and Henke // Am. J. Hum. Genet.-1999.-64.-P. 1473-1474.

47. Hurst L. D., Ellegren H. Sex biases in the mutation rate // Trends Genet.-1998.-14.-P. 446-452.

48. Kimura M., Ohta T. Distribution of allelic frequencies in a finite population under stepwise production of neutral alleles // Proc. Nat. Acad. Sci. USA.-1975.-72.-P. 2761-2764.

49. Никитина T. B., Назаренко C. А. Мутации в микросателлитных повторах ДНК и эмбриональная гибель у человека // Генетика.-2000.-36, № 7.-С. 965-971.

50. Kodaira M., Satoh C., Hiyama K., Toyama K. Lack of effects of atomic bomb radiation on genetic instability of tandem-repetitive elements in human germ cells // Am. J. Hum. Genet.-1995.-57.-P. 1275-1283.

51. Dubrova Y. E., Nesterov V. N., Krouchinsky N. G. Further evidence for elevated human minisatellite mutation rate in Belarus eight years after the Chernobyl accident // Mutat. Res.-1997.-381.-P. 267-278.

52. Dubrova Y. E., Bersimbaev R. I., Djansugurova M. K. Nuclear weapons tests and human germline mutation rate // Science.-2002.-N 5557.-P. 1037.

53. Chen X., Stroun M., Magnenat J. L. Microsatellite alterations in plasma DNA of small lung cancer patients // Nat. Med.-1996.-2.-P. 1033-1035.

54. Rush E. B., Calvano J. E., van Zee K. J. Microsatellite instability in breast cancer // Ann. Surg. Oncol.-1997.-4.P. 310-315.

55. Spandidos D. A., Koumantakis E., Sifakis S. Microsatellite mutations in spontaneously aborted embryos // Fertility and Sterility.-1998.-5.-P. 892-895.

56. Никитина Т. В., Лебедев И. Н., Суханова Н. Н., Назаренко $C$. $A$. Гаметические мутации тетрануклеотидных повторов ДНК в норме и патологии раннего периода онтогенеза человека // Генетика.-2005.-41, № 7.-С. 943-953.

57. Животовский Л. А. Статистические методы анализа частот генов в природных популяциях // Итоги науки и техники.-М.: ВИНИТИ, 1983.-Т. 8.-С. 76-104.

58. Loeb L. A. Cancer cells exhibit a mutator phenotype // Adv. Cancer Res.-1998.-72.-P. 25-56.

59. Amarger V., Gauguier D., Yerle M., Apiou F., Pinton P., Giraudeau F., Monfouilloux S., Lathrop M., Dutrillaux B., Buard J., Vergnaud G. Analysis of the human, pig, and rat genomes supports a universal telomeric origin of minisatellite sequences // Genomics.-1998.-52.- P 62-71.

60. Kimpton C. P., Hopgood R., Watson S. K., Gill P., Sullivan K. Cloning and characterisation of novel single locus probes for forensic purposes // Adv. Forensic Haemogenet.-1992.4.-P. 129-131. 